IDUHeS, 2021; 4(3): 327-338

Doi: 10.52538/iduhes. 1033115

Araştırma Makalesi-Research Paper

\title{
HEMŞİRELERIN KANITA DAYALI UYGULAMALARA YÖNELİK TUTUMLARI: TANIMLAYICI BİR ÇALIŞMA
}

\section{THE RELATIONSHIP BETWEEN NURSES' ATTITUDES TOWARDS EVIDENCE- BASED PRACTICES: A DESCRIPTIVE STUDY}

\author{
Özcan AYGÜN', Menevșe YILDIRIM²
}

\begin{abstract}
Özet
Klinik uygulamaların kanıta dayalı olarak gerçekleştirilmesi hemşirenin mesleki sorumluluklarındandır. Hemşirelikte nitelikli bakımın sağlanması, bağımsız karar verilmesi ve mesleğin profesyonelleşmesinde kanıta dayalı uygulamaların önemi giderek artmaktadır. Bu araştırmanın amacı hemşirelerin kanıta dayalı uygulamalara yönelik tutumlarının belirlenmesidir. Tanımlayıcı türdeki bu araştırmanın evrenini Fethiye'deki kamu ve özel hastanelerde çalışan tüm hemşireler oluşturmaktadır. Araştırmada ulaşılabilir örnekleme yöntemi kullanılmış ve araştırmaya katılmayı gönüllü olarak kabul eden tüm hemşireler çalışmaya dahil edilmiştir. Araştırmaya, katılım oranı \%63 olarak gerçekleşmiştir. Çalışmaya başlamadan önce etik kurul, kurum izni ve katılımcılardan onam alınmıştır. Araştırma verileri "Tanıtıcı Bilgi Formu” ve "Kanıta Dayalı Hemşireliğe Yönelik Tutum Ölçeği (KDHYTÖ)” kullanılarak toplanmıştır. Veri toplama formları çalışmaya katılmayı kabul eden 202 hemşireye uygulanmıştır. Verilerin değerlendirilmesinde; araştırmada sayı, yüzde ve ortalamalar, Mann Whitney U testi ve Kruskall Wallis H testi kullanılmıştır. Hemşirelerin, \%89.1'i kadın ve yaş ortalaması 32.41 \pm 9.6 'dır. Hemşirelerin \%38.'i lisans eğitimi mezunu, yarıdan fazlası özel hastanelerde $(\% 56.9)$ ve hastanelerin servislerinde (\%59.4) çalışmakta, bulundukları kurumlarda çalıșma süreleri ise ortalama 7.69 \pm 7.14 yıldır. Katılımcıların KDHYTÖ puan ortalaması 56.27 'dir. Hastanelerin servislerinde çalışan hemşirelerin ölçek ve alt boyut puan ortalamalarının acil, ameliyathane ve yoğun bakım gibi özellikli birimlerde çalışanlara, eğitim durumu lisans düzeyinde olanların lise ve ön lisans mezunlarına göre daha yüksek ve istatistiksel olarak anlamlı olduğu belirlenmiştir $(\mathrm{p}<.05)$. Ayrıca, kentsel alanda yaşamının çoğunu geçirenlerin kırsal kesimdekilere, mesleki yayınları takip edenlerin etmeyenlere, mesleki dernek üyeliği olanların olmayanlara göre puan ortalamalarının daha yüksek ve istatistiksel olarak anlamlı olduğu saptanmıştır ( $p<.05)$. Çalışmaya katılan hemşirelerin kanıta dayalı hemşireliğe yönelik tutumlarının olumlu yönde olduğu saptanmıștır. Lisans mezunlarının, daha çok kentsel alanda hayatını geçirmiş olanların, mesleki yayın okuyanların ve mesleki derneklere üye olanların kanıta dayalı hemşireliğe yönelik tutumlarının daha yüksek olduğu belirlenmiştir.
\end{abstract}

Anahtar Kelimeler: Hemşirelik, kanıta dayalı hemşirelik, kanıta dayalı uygulama, tutum.

Abstract

Performing clinical practices based on evidence is one of the professional responsibilities of the nurse. Evidence-based practices are becoming increasingly important in providing quality care in nursing, making independent decisions, and professionalizing the profession. The aim of this study is to determine the attitudes of nurses towards evidence-based practices. The universe of this descriptive study consists of all nurses working in public and private hospitals in Fethiye. Accessible sampling method was used in the study and all nurses who voluntarily agreed to participate in the study were included in the study. The participation rate in the research was $63 \%$. Ethics committee, institutional permission and consent of the participants were obtained before starting the study. The research data were collected using the "Descriptive Information Form" and the "Evidence-Based Attitude Scale towards Nursing (EBASN)". Data collection forms were applied to 202 nurses who agreed to participate in the study. In the evaluation of the data, frequencies, percent and averages, Mann Whitney $\mathrm{U}$ test and Kruskall Wallis $\mathrm{H}$ test were used. Of the nurses, $89.1 \%$ were women and the mean age was $32.41 \pm 9.6$ years. $38 \%$ of the nurses graduated from undergraduate education, more than half of them work in private hospitals $(56.9 \%)$ and hospital wards $(59.4 \%)$, and the average working period in the institutions they work in is 7.69 \pm 7.14 years. The average score of the participants in the EBASN is 56.27. It was determined that the scale and sub-dimension point averages of the nurses working in the wards of hospitals were higher and statistically significant compared to those working in specialized units such as emergency, operating room and intensive care, and those with undergraduate education level were higher than high school and associate degree graduates ( $\mathrm{p}<.05$ ). In addition, it was determined that those who spent most of their life in the urban area had a higher and statistically significant mean score than those who lived in rural areas, those who followed professional publications did not, and those who were members of professional associations compared to those who did not $(\mathrm{p}<.05)$. It was determined that the attitudes of the nurses participating in the study towards evidence-based nursing were positive. It has been determined that the attitudes of undergraduate graduates, those who have spent their lives in urban areas, those who read professional publications and those who are members of professional associations, towards evidence-based nursing are higher.

Keywords: Nursing, evidence-based nursing, evidence-based practice, attitude.

Geliş Tarihi (Received Date): 06.12.2021, Kabul Tarihi (Accepted Date):24.12.2021, Basım Tarihi (Published Date):27.12.2021 ${ }^{1}$ Muğla Sıtkı Koçman Üniversitesi Fethiye Sağlık Bilimleri Fakültesi, Hemşirelik Bölümü, Halk Sağlığı Hemşireliği Anabilimdalı, Muğla, ${ }^{2}$ Muğla Sıtk1 Koçman Üniversitesi Fethiye Sağlık Bilimleri Fakültesi, Hemşirelik Bölümü, Hemşirelikte Yönetim Anabilimdalı, Muğla E-mail: ozcanaygun@mu.edu.tr ORCID ID's: Ö.A.; https:/orcid.org/0000-0002-4566-3292, M.Y.; https:/orcid.org/0000-0001-6033-6196. 


\section{GíRiș}

Son yıllarda teknolojik gelişmelerle birlikte sağlık ve hemşirelik alanındaki araştırmalar hızla artmaktadır. Araştırmalar neticesinde değișen/yenilenen bilginin klinik uygulamalara seri bir şekilde entegrasyonu gerekmektedir. $\mathrm{Bu}$ durum kliniklerde geleneksel hemşirelik uygulamaları yerine kanıta dayalı hemşirelik uygulamalarını kullanmanın önemini artırmaktadır (André, Aune, \& Braend, 2016, ss. 30-35; Doğan, Aynur, Demirağ, \& Uçan, 2021, ss. 612-622; Jennings 2000, ss. 343-345). Türk Dil Kurumu kanıtı "bir şeyin doğruluğu, gerçekliği konusunda kanaat verici belge, delil, iz, argüman" olarak tanımlamaktadır (Türk Dil Kurumu, 2021). Kanıta dayalı uygulama ise; eldeki en iyi kanıtlar ile teorik bilgi, hasta tercihleri ve mevcut kaynakların sentezlenmesi ve hastanın tanı, tedavi ve bakımında kullanılmasidir (Ingersoll, 2000, ss. 151-152).

Uluslararası ve ulusal bağlamda hemşirelik uygulamalarının kanıta dayalı gerçekleştirilmesi konusu 1900'lü yıllardan bu yana ilgi görmektedir. Amerikan Hemşireler Yetki Belgelendirme Merkezi (American Nurses Credentialing Center-ANCC) hemşirelik bakımının mükemmelliğini sergileyen hastanelere "Magnet" etiketini vermektedir. Bir hastanenin Magnet statüsünde yer alması için araştırma yapması ve kanıta dayalı uygulamaları kullanması önemli bir rol oynamaktadır. ANCC'nin değerlendirme kriterlerinde; hastanelerdeki hemşirelik hizmetleri için belirlenen 14 zorunlu standarttan birisinin "araştırmaların ve kanıta dayalı uygulamaların klinik süreçlere entegre edilmesi" olduğu görülmektedir (Reigle, Stevens, Belcher, Huth, McGuire, Mals, ve ark., 2008, ss. 97-102). Kanıta dayalı uygulamalar Türkiye'deki mevzuat içerisinde de yer bulmuştur. Hemşirelik Yönetmeliğinde Değişiklik Yapılmasına Dair Yönetmelik ile daha önceki yönetmelikte de olduğu gibi hemşirenin görev, yetki ve sorumlulukları kısmında "Gereksinim duyulan hemşirelik bakımını kanıta dayalı olarak planlar ve yürütür." denilmektedir (Resmi Gazete Say1: 27910, Tarih: 19 Nisan 2011). Türk Hemşireler Derneği'nin Aralık 2009'da yayımlamış olduğu "Hemşireler için Etik İlke ve Sorumluluklar" broşüründe, hemşirenin "araştırmalarda ve kanita dayalı mesleki bilginin geliştirilmesinde sorumluluk üstlenmesi" gerektiği belirtilmektedir. Hemşirenin diğer mesleki sorumluluklarından olan nitelikli bakımı sağlaması, mesleki yeterliliğini sürdürmesi/yükseltmesi ve mesleki uygulamalarının sorumluluğunu üstlenmesinin temelinde kanıta dayalı uygulamalar bulunmaktadır (Türk Hemşireler Derneği, 2009).

Hemşirelerin kanıta dayalı uygulamaları öğrenmesini kolaylaştırmak amacıyla Pubmed, Joanna Briggs Enstitüsü, National Guideline Clearinghouse, Cochrane gibi çeşitli veri kaynakları sıklıkla kullanılmaktadır. Özellikle Cochrane, sağlık ve bakım ile ilgili en güvenilir kanıtları araştırmak, kanıt üretmek ve bu bilgileri Dünya çapında duyurmaya öncülük eden en kapsamlı veri tabanlarından bir tanesidir (https://www.cochrane.org/about-us, 2021). Ontario Kayıtlı Hemşireler Birliği de (Registered Nurses' Association of Ontario-RNAO) iyi uygulama rehberleri aracılığı ile kanıta dayalı bilgilerin hemşirelere ulaşmasını sağlamaktadır (RNAO, 2021).

Kanıta dayalı uygulamalar sayesinde hemşireler yetkilerini daha bağımsız kullanabileceği gibi otonom kararlar alabilecek ve mesleğin profesyonelleşmesine katk1 sağlayabilecektir (Şadi Şen, \& Yurt, 2021, ss. 102-107). Çünkü, kanıta dayalı uygulamalar ile hemşireler hastalara yaptıkları girişimlere ilişkin sorumluluk alacak ve hemşirelik bakımı hesap verilebilir bir şekilde sunulacaktır. Wilson ve arkadaşları (2015) kanıta dayalı uygulamaların hemşireleri güçlendirmenin bir yolu olarak görüldüğünü ve yapısal güçlendirmenin bir boyutu olarak ele alındığını belirtmektedir.

Kanıta dayalı uygulamaların gelişebilmesi için hemşirelerin kanıta dayalı uygulamalara yönelik farkındalı̆̆ının artması ve kanıta dayalı uygulamalara yönelik olumlu bir tutum 
geliştirmeleri gerekmektedir (Doğan ve ark. 2021, ss. 612-622). Ancak sağlık kurumlarında hemşirelerin uygulamalarını kanıta dayalı gerçekleştirme oranı oldukça düşüktür (Koehn, \& Lehman, 2008, ss. 209-215) ve hemşirelerin kanıta dayalı uygulamalara katılımını artırmanın yolları henüz tam olarak bilinmemektedir (Wilson ve ark., 2015, ss. 12-21). Kanıta dayalı uygulama kültürünün geliştirilmesinde hemşirelerin bilgi, tutum, uygulamalarının tanımlanması, anlaşılması öncelikli ve önemli adımlardan bir tanesidir. Bu çalışmanın amacı; hemşirelerin kanıta dayalı uygulamalara yönelik tutumunun belirlenmesidir.

\section{YÖNTEM}

\subsection{Araştırmanın tipi}

Tanımlayıcı tasarımdadır.

\subsection{Araştırmanın yeri ve zamanı}

Bu çalışma, Fethiye'de bulunan bir kamu ve iki özel hastanede gerçekleştirilmiştir. Kamu hastanesi 200 yatak kapasitesine sahip ve 200 hemşire ile hizmet vermektedir. Özel hastanelerden bir tanesi 100 yatak sayısı 110 hemşire ile hizmet verirken diğer özel hastane ise 10 yatak sayısı 10 hemşire ile hizmet vermektedir. Bu araştırma 01-31 Ağustos 2017 tarihleri arasında yürütülmüştür.

\subsection{Evren ve örneklem}

Araştırmanın evrenini araştırma verilerinin toplandığı tarihte hastanelerde çalışmakta olan toplam 320 hemşire oluşturmaktadır. Araştırmada ulaşılabilir örnekleme yöntemi kullanılmış ve araştırmaya katılmayı gönüllü olarak kabul eden tüm hemşireler çalışmaya dahil edilmiştir. Araştırmaya katılmak gönüllülük esasına dayalı olduğundan kamu hastanesinden 87 hemşire ve özel hastanelerden 115 hemşire olmak üzere toplam 202 hemşire ile çalışma tamamlanmıştır. Araştırmaya katılım oranı kamu hastanesinde \% 43.5 ve özel hastanelerde ise $\% 95.8$ 'dir. Genel katılım oranı \%63 olarak gerçekleşmiştir.

\subsection{Araştırmanın etik yönü}

Araştırma gerçekleştirilirken Helsinki Deklerasyonu Prensipleri'ne uyulmuştur. Araştırmanın gerçekleştirilmesi için Muğla Sıtkı Koçman Üniversitesi İnsan Araştırmaları Etik Kurulu'ndan 170002 sayı ve 26.07.2017 tarihi ile etik kurul onayı alınmıştır. Fethiye'de bulunan özel ve kamu hastane yetkililerinden kurum izinleri ve ölçeği Türkçe 'ye uyarlayan Yasemin Ayhan'dan da ölçek kullanım izni alınmıştır. Ayrıca araştırma katılımcılarından da onam alınmıştır.

\subsection{Veri toplama araçları}

Araştırma verilerinin toplanmasında, "Tanıtıcı Bilgi Formu" ve "Kanıta Dayalı Hemşireliğe Yönelik Tutum Ölçeği (KDHYTÖ)" kullanılmıştır.

\subsubsection{Tanıtıcı bilgi formu}

Örneklem özelliklerini belirlemek için araştırmacılar tarafından oluşturmuştur. Formda hemşirelerin yaş, cinsiyet, eğitim durumu, çalıştıkları kurum (özel, kamu), çalıştıkları birim, kurumda çalışma süresi, çoğunlukla yaşadıkları yer (kent, kırsal), mesleki derneklere üyelik, araştırma yapma isteği, mesleki yayın okuma olmak üzere toplam 10 soru yer almaktadır.

\subsubsection{Kanıta dayalı hemşireliğe yönelik tutum ölçeği}

Hemşirelerin kanıta dayalı uygulama konusundaki tutumlarını değerlendirmek amacıyla Ruzafa-Martinez ve arkadaşları (2011) tarafından geliştirilen ölçek, "kanıta dayalı hemşireliğe yönelik inanç ve beklentiler" (7 madde), "kanıta dayalı uygulama niyeti" (4 madde) ve "kanıta dayalı hemşirelikle ilgili duygular" (4 madde) olmak üzere 3 alt boyuttan ve 15 maddeden oluşmaktadır (Ruzafa-Martínez, López-Iborra, \& Madrigal-Torres, 2011, ss. 664-670). Ölçek 
maddeleri olumlu (sekiz madde: 1, 2, 5, 7, 9, 11, 13 ve 14. maddeler) ve olumsuz (yedi madde: $3,4,6,8,10,12$ ve 15. maddeler) ifadeler içermektedir. Ölçeğin puanlanmasında olumsuz maddeler ters çevrilerek kodlanmaktadır. Beşli Likert tipine ( 1 =hiç katılmıyorum, 2=katılmıyorum, 3=biraz katıliyorum, 4=katıllyorum, 5=tamamen katıllyorum) göre hazırlanan ölçekten en düşük 15 puan, en yüksek 75 puan alınmaktadır. Ölçeğin kesme noktası yoktur, ölçekten yüksek puan alınması kanıta dayalı hemşireliğe yönelik tutumun olumlu olduğunu göstermektedir (Ruzafa-Martinez ve ark., 2011, ss. 664-670). Ölçeğin Türkçe uyarlanması Ayhan ve ark. (2015) tarafindan yapılmış, KDHYTÖ geçerli ve güvenilir bulunmuştur. Ölçeğin Cronbach Alpha katsayısı 0.90, "kanıta dayalı hemşireliğe yönelik inanç ve beklentiler" alt boyutu 0.86, "kanita dayalı uygulama niyeti" alt boyutu 0.69 ve alt boyutu ise 0.71'dir (Ayhan, Kocaman, \& Bektaş, 2015, ss. 21-35).

\subsection{Verilerin toplanması}

Veriler, araştırmacı tarafından 01-31 Ağustos 2017 tarihleri arasında kliniklere gidilerek toplanmıştır. Araştırmacı, araştırmanın amacını açıklayarak hemşireleri araştırmaya katılıma davet etmiş ve araştırmaya katılmayı gönüllü olarak kabul eden hemşirelere veri formlarını dağıtmıştır. İki hafta içerisinde veri toplama formları kliniklere tekrar gidilerek hatırlatılmış ve toplanmıştır. Araştırmaya katılmaya gönüllü olan ancak yoğun mesai nedeniyle veri formlarını dolduramayan çalışanlara bir hafta ek süre verilmiştir. Veri formunun doldurulması ortalama on dakika sürmektedir.

\subsection{Verilerin değerlendirilmesi}

Araştırma verilerinin analizinde SPSS (Statistical Package For Social Sience) 22.0 paket programı kullanılmıştır. Verilerin normal dağılıma uygunluğunu belirlemek için Shapiro Wilk testi ve Skewness ve Kurtosis değerleri de dikkate alınmıştır. Skewness ve Kurtosis değerleri \pm 1 değeri içindeyse verilerin normal dağılıma uygun olduğu kabul edilmiştir (Gravetter, \& Wallnau, 2014, ss. 151-152). Araştırmadaki verilerin analizinde frekans değerleri (sayı ve yüzdelik dilim), bağımsız değişkenlerle ölçek puanları arası çapraz karşılaştırma yapılırken ikili değişkenlerde bağımsız değişken Mann Whitney U testi, üç ve daha fazla olan gruplardaki değişkenlerin ölçek puanlarıyla karşılaştırılmasında Kruskall Wallis H testi kullanılmıştır. Tüm istatistiksel değerlendirmelerde $\mathrm{p}<.05$ anlamlılık düzeyi olarak kabul edilmiştir.

\section{BULGULAR}

Araştırmaya katılan hemşirelerin \%89.1'i kadın ve yaş ortalaması $32.41 \pm 9.6$ 'dır. Hemşirelerin \%38.'i lisans mezunu, yarıdan fazlası özel hastanelerde (\%56.9) ve servislerde (\%59.4) çalışmakta, bulundukları kurumlarda çalışma süreleri ise ortalama 7.69 \pm 7.14 yıldır. Hemşirelerin büyük bir kısmı yaşamlarının çoğunu kırsal (\%79.7) alanda geçirmiş, \%78.2'i mesleği isteyerek seçmiş, meslek seçiminde çoğunlukla iş bulma kolaylı̆̆ 1 (\%39.6) etkili olmuştur. Hemşirelerin yaklaşık üçte biri (\%33.2) araştırma yapma isteği olduğunu ve mesleki yayınları okuduğunu (\%35.1) bildirmesine rağmen sadece \%12.9'u mesleki derneklere üye olduğunu belirtmiştir (Tablo 1). 
Tablo 1. Araştırmaya Katılan Hemşirelerin Tanıtıcı Bilgileri

\begin{tabular}{|c|c|c|c|}
\hline Değişkenler & Kategoriler & $\mathbf{n}$ & $\%$ \\
\hline \multirow{2}{*}{ Cinsiyet } & Kadın & 180 & 89.1 \\
\hline & Erkek & 22 & 10.9 \\
\hline \multirow{3}{*}{ Yaş } & $18-25$ yaş & 69 & 34.2 \\
\hline & $26-40$ yaş & 87 & 43.0 \\
\hline & 41 yaş ve üzeri & 46 & 22.8 \\
\hline \multirow{3}{*}{ Eğitim durumu } & Lise & 78 & 38.6 \\
\hline & Ön lisans & 47 & 23.3 \\
\hline & Lisans & 77 & 38.1 \\
\hline \multirow{2}{*}{ Çalışılan hastane türü } & Özel hastane & 115 & 56.9 \\
\hline & Kamu hastanesi & 87 & 43.1 \\
\hline \multirow[b]{2}{*}{ Çalışılan birim } & Servisler & 120 & 59.4 \\
\hline & $\begin{array}{l}\text { Özellikli birim (acil servis, yoğun } \\
\text { bakım, ameliyathane, diyaliz) }\end{array}$ & 82 & 40.6 \\
\hline \multirow{3}{*}{ Kurumda çalışma yılı } & $1-5 \mathrm{y} 1 \mathrm{l}$ & 110 & 54.5 \\
\hline & $6-10$ yil & 38 & 18.8 \\
\hline & 11 yil ve üzeri & 54 & 26.7 \\
\hline \multirow{2}{*}{$\begin{array}{l}\text { Yaşamınızın çoğunda yaşadığınız } \\
\text { yer }\end{array}$} & Kent & 41 & 20.3 \\
\hline & Kır (ilçe, bucak, köy vb.) & 161 & 79.7 \\
\hline \multirow{2}{*}{ Araştırma yapma isteği } & Var & 67 & 33.2 \\
\hline & Yok & 135 & 66.8 \\
\hline \multirow{2}{*}{ Mesleki yayınları okuma } & Evet & 71 & 35.1 \\
\hline & Hayır & 131 & 64.9 \\
\hline \multirow{2}{*}{ Mesleki derneklerine üyelik } & Var & 26 & 12.9 \\
\hline & Yok & 176 & 87.1 \\
\hline Toplam & & 202 & 100.0 \\
\hline
\end{tabular}

Tablo 2'de hemşirelerin KDHYTÖ'den ve alt boyutlarından aldıkları puan ortalamaları gösterilmiştir. Hemşirelerin KDHYTÖ genelinde puan ortalaması $53.27 \pm 11.83$ iken ölçek alt boyutlarının puan ortalamaları; "kanıta dayalı hemşireliğe yönelik inanç ve beklentiler" alt boyutunda $25.26 \pm 6.61$, "kanita dayalı uygulama niyeti" alt boyutunda $13.30 \pm 3.09$ ve alt boyutunda 14.70 \pm 3.61 olarak hesaplanmıştır (Tablo 2).

Tablo 2. Kanıta Dayalı Hemşireliğe Yönelik Tutum Ölçeği ve Alt Boyutları Puan

Ortalamaları

\begin{tabular}{lccccc}
\hline Ölçek ve alt boyutları & n & Ort. & SS & Min-Max & $\begin{array}{c}\text { Madde } \\
\text { sayısı }\end{array}$ \\
\hline $\begin{array}{l}\text { Kanıta dayalı } \\
\text { hemşireliğe yönelik } \\
\text { inanç ve beklentiler }\end{array}$ & 202 & 25.26 & 6.61 & $7.00-35.00$ & 7 \\
\hline $\begin{array}{l}\text { Kanıta dayalı uygulama } \\
\text { niyeti }\end{array}$ & 202 & 13.30 & 3.09 & $4.00-18.00$ & 4 \\
\hline $\begin{array}{l}\text { Kanita dayalı } \\
\text { hemşirelikle ilgili } \\
\text { duygular }\end{array}$ & 202 & 14.70 & 3.61 & $4.00-20.00$ & 4 \\
\hline $\begin{array}{l}\text { KDHYTÖ } \\
\text { KDHYTÖ: Kanıta Dayalı Hemșireliğe Yönelik Tutum Ölçeği }\end{array}$ & & \\
\hline
\end{tabular}

Hemşirelerin tanıtıcı özelliklerinden; cinsiyet, özel ya da kamu hastanelerinde çalışma durumları, kurumda çalışma süresi, araştırma yapma isteği, mesleki dernek üyeliği ile KDHYTÖ ve alt boyutlarının puan ortalamaları arasında istatistiksel olarak anlamlı farklılık olmadığı belirlenmiştir ( $\mathrm{p}>.05$ ) (Tablo 3). Hemşirelerin yaş gruplarına göre KDHYTÖ, "kanıta 
dayalı uygulama niyeti", alt boyut puan ortalamalarında anlamlı bir farklılık saptanmazken, inanç ve beklenti alt boyut puan ortalamalarının $(\mathrm{KWH}=6.73 \mathrm{p}=.034)$ karşılaştırılması istatistiksel olarak anlamlıdır. Ancak yapılan çoklu karşılaştırmalar sonucunda bu farklılığın anlamlı olmadığı belirlenmiştir ( $\mathrm{p}>$.05) (Tablo 3).

Tablo 3. Hemşirelerin Tanıtıcı Özellikleri ile Kanıta Dayalı Hemşireliğe Yönelik Tutum Ölçeği ve Alt Boyutları Puan Ortalamalarının Karşılaștırılması ( $(\mathrm{n}=\mathbf{2 0 2})$

\begin{tabular}{|c|c|c|c|c|c|c|c|c|}
\hline \multirow{2}{*}{$\begin{array}{l}\text { Değişkenler } \\
\text { Cinsiyet }\end{array}$} & \multirow{2}{*}{$\begin{array}{c}\text { Sayı } \\
\mathbf{n}\end{array}$} & \multicolumn{2}{|c|}{$\begin{array}{c}\text { Kanıta dayalı } \\
\text { hemşireliğe yönelik } \\
\text { inanç ve beklentiler }\end{array}$} & \multicolumn{2}{|c|}{$\begin{array}{c}\text { Kanita dayalı } \\
\text { uygulama } \\
\text { niyeti }\end{array}$} & \multicolumn{2}{|c|}{$\begin{array}{c}\text { Kanita dayalı } \\
\text { hemşirelikle ilgili } \\
\text { duygular }\end{array}$} & \multirow{2}{*}{\begin{tabular}{|l|} 
KDHYTÖ \\
Ort. $\quad$ SS
\end{tabular}} \\
\hline & & Ort. & SS & Ort. & SS & Ort. & SS & \\
\hline Kadın & 180 & 25.30 & 6.44 & 13.37 & 3.07 & 14.76 & 3.58 & $53.43 \quad 11.68$ \\
\hline \multirow[t]{2}{*}{ Erkek } & & 24.95 & 7.98 & 12.77 & 3.29 & 14.22 & 3.85 & $51.95 \quad 13.24$ \\
\hline & & \multicolumn{2}{|c|}{$\begin{array}{l}\mathrm{z}=-.68 \\
\mathrm{p}=.495\end{array}$} & \multicolumn{2}{|c|}{$\begin{array}{l}\mathrm{z}=-1.13 \\
\mathrm{p}=.255\end{array}$} & \multicolumn{2}{|c|}{$\begin{array}{l}\mathrm{z}=-.61 \\
\mathrm{p}=.539\end{array}$} & $\begin{array}{l}\mathrm{z}=-.23 \\
\mathrm{p}=.816\end{array}$ \\
\hline \multicolumn{9}{|l|}{ Yaş } \\
\hline $18-25$ yaş & 69 & 26.37 & 5.52 & 13.71 & 2.15 & 14.89 & 3.16 & $54.98 \quad 9.22$ \\
\hline $26-40$ yas & 87 & 23.77 & 7.43 & 12.74 & 3.57 & 14.64 & 3.83 & $51.16 \quad 13.19$ \\
\hline \multirow[t]{2}{*}{41 yaş ve üzeri } & 46 & 26.41 & 6.00 & 13.76 & 3.22 & 14.52 & 3.85 & $54.69 \quad 12.22$ \\
\hline & & \multicolumn{2}{|c|}{$\begin{array}{c}\mathrm{KWH}=6.73 \\
\mathbf{p}=.034\end{array}$} & \multicolumn{2}{|c|}{$\begin{array}{c}\mathrm{KWH}=2.80 \\
\mathrm{p}=.247\end{array}$} & \multicolumn{2}{|c|}{$\begin{array}{c}\mathrm{KWH}=.01 \\
\mathrm{p}=.998\end{array}$} & $\begin{array}{c}\mathrm{KWH}=3.77 \\
\mathrm{p}=.152\end{array}$ \\
\hline \multicolumn{9}{|l|}{ Ĕ̆itim durumu } \\
\hline Lise & 78 & 25.19 & 5.52 & 12.94 & 2.58 & 13.87 & 3.25 & $52.01 \quad 9.24$ \\
\hline Ön lisans & 47 & 23.31 & 8.62 & 12.78 & 3.39 & 14.14 & 3.40 & $50.25 \quad 14.45$ \\
\hline \multirow[t]{2}{*}{ Lisans } & 77 & 26.51 & 5.97 & 13.98 & 3.29 & 15.88 & 3.80 & $56.38 \quad 11.85$ \\
\hline & & \multicolumn{2}{|c|}{$\begin{array}{c}\mathrm{KWH}=5.83 \\
\mathrm{p}=.054\end{array}$} & \multicolumn{2}{|c|}{$\begin{array}{c}\text { KWH }=12.03 \\
p=.002\end{array}$} & \multicolumn{2}{|c|}{$\begin{array}{c}\text { KWH }=23.44 \\
\mathbf{p}<.001\end{array}$} & $\begin{array}{l}\text { KWH } \\
=17.18 \\
\text { p }<.001\end{array}$ \\
\hline \multicolumn{9}{|l|}{ Çalıșılan hastane türü } \\
\hline Özel & 115 & 24.97 & 7.76 & 12.95 & 3.60 & 14.81 & 4.00 & $52.74 \quad 14.01$ \\
\hline \multirow[t]{3}{*}{ Kamu } & 87 & 25.64 & 4.68 & 13.77 & 2.19 & 14.55 & 3.04 & $53.96 \quad 8.13$ \\
\hline & & \multirow{2}{*}{\multicolumn{2}{|c|}{$\begin{array}{l}\mathrm{z}=-1.23 \\
\mathrm{p}=.216\end{array}$}} & & & & & $\mathrm{z}=-.89$ \\
\hline & & & & & & & & $\mathrm{p}=.376$ \\
\hline Çalışılan birim & & & & & & & & \\
\hline Servisler & 120 & 26.41 & 5.07 & 13.87 & 2.74 & 15.24 & 3.09 & 55.53 \\
\hline Özellikli birim (acil servis, & & 2357 & & & 340 & 1201 & 115 & $4996 \quad 14.13$ \\
\hline Uy ante) & & & & $\mathrm{z}=-$ & & & & $7=-2.41$ \\
\hline & & & & $\mathrm{p}=$ & & & & $p=.016$ \\
\hline Kurumda çalışma süresi & & & & & & & & \\
\hline 5 y1l ve alt1 & 110 & 25.22 & 6.65 & 13.42 & 2.94 & 14.68 & 3.44 & $53.33 \quad 11.44$ \\
\hline $6-10$ y1l aras 1 & 38 & 24.34 & 6.76 & 13.18 & 3.08 & 14.92 & 3.78 & $52.44 \quad 12.38$ \\
\hline 11 yıl ve üzeri & 54 & 25.98 & 6.44 & 13.14 & 3.44 & 14.59 & 3.88 & $53.72 \quad 12.42$ \\
\hline & & $\begin{array}{r}\mathrm{KWl} \\
\mathrm{p}=\end{array}$ & 76 & $\begin{array}{c}\mathrm{KWH} \\
\mathrm{p}=\end{array}$ & $=.14$ & $\begin{array}{r}\mathrm{KW} \\
\mathrm{p}=\end{array}$ & 15 & $\begin{array}{c}\mathrm{KWH}=.47 \\
\mathrm{p}=.788\end{array}$ \\
\hline Yaşanılan yer & & & & & & & & \\
\hline Büyükşehir-il merkezi & 41 & 27.41 & 4.44 & 14.04 & 2.13 & 15.51 & 3.27 & 56.97 \\
\hline İlce-Bucak-Köy & 161 & 24.71 & 6.96 & 13.11 & 3.27 & 14.49 & 3.67 & $52.32 \quad 12.44$ \\
\hline & & & & $\mathrm{z}=-$ & & & & $\mathrm{z}=-\mathbf{2 . 0 0}$ \\
\hline & & & & $\mathrm{p}=$ & & & & $p=.045$ \\
\hline raşt & & & & & & & & \\
\hline Var & 67 & 24.89 & 6.91 & 13.58 & 2.85 & 15.11 & 3.75 & 53.59 \\
\hline Yok & 135 & 25.44 & 6.47 & 13.17 & 3.21 & 14.49 & 3.53 & 53.11 \\
\hline
\end{tabular}




\begin{tabular}{|c|c|c|c|c|c|c|c|c|c|}
\hline & & \multicolumn{2}{|c|}{$\begin{array}{c}\mathrm{z}=.16 \\
\mathrm{p}=.871\end{array}$} & \multicolumn{2}{|c|}{$\begin{array}{l}z=-.62 \\
p=.531\end{array}$} & \multicolumn{2}{|c|}{$\begin{array}{l}\mathrm{z}=-1.62 \\
\mathrm{p}=.105\end{array}$} & $\begin{array}{l}\mathrm{z}=- \\
\mathrm{p}=.\end{array}$ & \\
\hline \multicolumn{10}{|l|}{ Mesleki yayınları okuma } \\
\hline Evet & 71 & 26.40 & 6.11 & 13.46 & 2.89 & 15.38 & 3.76 & 55.25 & 11.68 \\
\hline Hayır & 131 & 24.64 & 6.80 & 13.22 & 3.21 & 14.33 & 3.48 & 52.19 & 11.82 \\
\hline & & \multicolumn{2}{|c|}{$\begin{array}{l}\mathrm{z}=-1.82 \\
\mathrm{p}=.069\end{array}$} & \multicolumn{2}{|c|}{$\begin{array}{l}\mathrm{z}=-.40 \\
\mathrm{p}=.686\end{array}$} & \multicolumn{2}{|c|}{$\begin{array}{l}z=-2.40 \\
p=.017\end{array}$} & \multicolumn{2}{|c|}{$\begin{array}{l}\mathrm{z}=-1.83 \\
\mathrm{p}=.067\end{array}$} \\
\hline \multicolumn{10}{|l|}{ Mesleki dernek üyeliği } \\
\hline Var & 26 & 25.00 & 6.78 & 13.46 & 3.17 & 15.00 & 3.74 & 53.46 & 12.82 \\
\hline \multirow[t]{2}{*}{ Yok } & 176 & 25.30 & 6.60 & 13.28 & 3.09 & 14.65 & 3.60 & 53.24 & 11.72 \\
\hline & & \multicolumn{2}{|c|}{$\begin{array}{l}\mathrm{z}=-.08 \\
\mathrm{p}=937\end{array}$} & \multicolumn{2}{|c|}{$\mathrm{z}=-.60$} & \multicolumn{2}{|c|}{$z=-.64$} & \multicolumn{2}{|c|}{$\begin{array}{l}\mathrm{z}=-.38 \\
\mathrm{p}=702\end{array}$} \\
\hline
\end{tabular}

Hemşirelerin eğitim durumları ile KDHYTÖ (KWH=17.18, p=<.001), "kanıta dayalı uygulama niyeti" (KWH =12.03, p=.002) ve "kanıta dayalı hemşirelikle ilgili duygular" (KWH $=23.44, \mathrm{p}=<.001$ ) puan ortalamaları arasında istatistiksel olarak anlamlı farklılık olduğu, ancak, "kanıta dayalı hemşireliğe yönelik inanç ve beklentiler" alt boyutunda bu farkın istatistiksel olarak anlamlı olmadığ belirlenmiştir ( $\mathrm{p}>.05$ ) (Tablo 3). Yapılan çoklu karşılaştırmalar sonucunda, lisans mezunu hemşirelerin KDHYTÖ, "kanıta dayalı uygulama niyeti" ve "kanıta dayalı hemşirelikle ilgili duygular" alt boyutu puan ortalamalarının hem lise hem de ön lisans mezunu hemşirelerden daha yüksek ve istatistiksel olarak anlamlı olduğu saptanmıştır ( $\mathrm{p}<.05)$.

Hastanelerin servislerinde çalışan hemşirelerin KDHYTÖ (z=-2.41, p=.016), "kanıta dayalı uygulama niyeti" ( $\mathrm{z}=-3.29, \mathrm{p}=.001)$ puan ortalamalarının acil servis, yoğun bakım, ameliyathane, diyaliz gibi özellikli birimlerde çalışanlara göre daha yüksek olması istatistiksel olarak anlamlı iken, "kanıta dayalı uygulamaya yönelik inanç ve beklentiler" ve alt boyutlarında bu farkın istatistiksel olarak anlamlı olmadığı belirlenmiştir ( $\mathrm{p}>.05$ ) (Tablo 3).

Araştırmanın yapıldığı yıla kadar yaşamının çoğunu kentsel yerleşim yerlerinde geçirenlerin KDHYTÖ $(\mathrm{z}=2.88, \mathrm{p}=.005)$ ve inanç ve beklenti $(\mathrm{z}=3.05, \mathrm{p}=.003)$ alt boyutlarının puan ortalamalarının kırsal yerleşim yerlerinde olanlara göre daha yüksek olması istatistiksel olarak anlamlıdır. Ancak, "kanıta dayalı uygulama niyeti" ve "kanıta dayalı hemşirelikle ilgili duygular" alt boyut puan ortalamalarında bu farkın istatistiksel olarak anlamlı olmadığ belirlenmiştir ( $\mathrm{p}>$.05) (Tablo 3).

Mesleki yayınları takip eden hemşirelerin "kanıta dayalı hemşirelikle ilgili duygular" $(\mathrm{z}=-2.40, \mathrm{p}=.017)$ puan ortalamalarının okumayanlara göre daha yüksek olması istatistiksel olarak anlamlıdır. Ancak mesleki yayınları takip eden hemşirelerin KDHYTÖ, inanç ve beklenti ile "kanıta dayalı uygulama niyeti" alt boyut puan ortalamaları arasında istatistiksel olarak anlamlı bir farklılık saptanmamıştır (p>.05) (Tablo 3).

\section{TARTIŞMA}

$\mathrm{Bu}$ araştırma, hemşirelerin kanıta dayalı uygulamaya yönelik tutumları incelenmiştir.

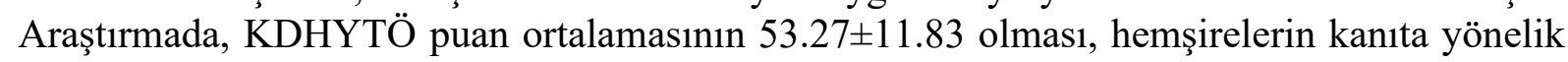
tutumlarının olumlu olduğu söylenebilir. Literatürde hemşirelerin kanıta dayalı hemşireliğe yönelik tutumlarının farklılık gösterdiği belirlenmiştir. Gerçekleştirilen bazı çalışmalarda KDHYTÖ puan ortalamaları bu araştırmadan düşük iken (Menekli, \& Korkmaz, 2021, ss. 3847; Şadi Şen, \& Yurt 2021, ss. 102-107; Y1lmaz, Düzgün, \& Dikmen, 2019, ss. 713-719) bazılarında bu araştırmadakinden yüksek (Aslan, \& Gürdap, 2021, ss. 84-98; Ayhan ve ark., 2015, ss. 21-35; Baran, Atasoy, \& Şahin, 2020, ss. 352-359; Daştan, \& Hintistan, 2018, ss. 1- 
9; Doğan ve ark., 2021, ss. 612-622; Doğan, Karaçay, Arslan, Yurtseven, Nazik, \& Yüksekkaya, 2019, ss. 39-45) bulunmuştur. Hemşirelerin kanıta dayalı hemşireliğe yönelik tutumlarının olumlu olduğu saptanmıştır (Doğan ve ark., 2021, ss. 612-622; Koehn, \& Lehman; 2008, ss. 209-215; Menekli, \& Korkmaz, 2021, ss. 38-47; Şadi Şen, \& Yurt 2021, ss. 102-107; Y1lmaz ve ark., 2019, ss. 713-719). Ancak Baran, Atasoy, Şahin (2020) ile Aslan ve Gürdap'ın (2021) çalışmalarında kanıta dayalı tutumların yüksek düzeyde olduğu belirlenmiştir. Araştırmaların farklı kurumlarda, farklı örneklemlerle ve farklı çalışma deseni ile (ön test-son test tek gruplu yarı deneysel) gerçekleştirilmesi bu farklılığa yol açmış olabilir. Genellikle tutumların orta düzey ve üzerinde olması hemşirelerin bu konuya aşina olduğunu ancak bilme ve davranışa dönüştürme konularında yetersizliklerin devam ettiğini düşündürmektedir.

Ölçek alt boyutları incelendiğinde; hemşirelerin "kanıta dayalı hemşireliğe yönelik inanç ve beklentiler" alt boyutu puan ortalaması $25.26 \pm 6.61$ bulunmuştur. Gerçekleştirilen diğer çalışmalarda da hemşirelerin puan ortalamalarının 25-30 puan arasında olduğu belirlenmiştir (Aslan, \& Gürdap, 2021, ss. 84-98; Ayhan ve ark., 2015, ss. 21-35; Baran ve ark, 2020, ss. 352-359; Daştan, \& Hintistan, 2018, ss. 1-9; Doğan ve ark., 2021, ss. 612-622; Y1lmaz ve ark., 2019, ss. 713-719). Hemşirelerin kanıta dayalı hemşireliğe yönelik inançları ve beklentileri kanıta dayalı tutum geliştirmelerinde önemlidir (Menekli, \& Korkmaz, 2021, ss. 38-47). Hem gerçekleştirilen çalışmada hem de diğer çalışmalarda hemşire kanıta dayalı inançlarının orta düzeyde olması, hemşirelerin kanıta dayalı uygulamaların faydasına inandığını göstermektedir. Hemşirelerin bu hazır oluş durumunun firsat olarak değerlendirilmesi ve hemşirelerin bakım uygulamalarında bu inancı davranışa dönüştürmelerinin desteklenmesi gerekmektedir.

Ölçek alt boyutlarından "kanıta dayalı uygulama niyeti" alt boyutundan hemşireler 13.30 \pm 3.09 puan ortalamasına sahiptir. Literatürde hemşirelerin puan ortalamalarının 10-16 arasında olduğu görülmektedir (Aslan, \& Gürdap 2021, ss. 84-98; Doğan ve ark., 2021, ss. 612622) "kanıta dayalı uygulama niyeti", hemşirelerin algıladıkları engelleri, kanıta dayalı uygulamaları yapma niyetlerini, iş yükünü ve kanıta dayalı uygulamalar için ayırdıkları süreyi göstermektedir (Ayhan ve ark., 2015, ss. 21-35). Çalışmalarda hemşirelerin "kanıta dayalı uygulama niyetinin" olumlu yönde olduğu belirlenmiştir. Hemşirelerin "kanıta dayalı uygulama niyeti” olmasına karşın bu niyetin artırılması gerektiği görülmektedir.

KDHYTÖ "kanıta dayalı hemşirelikle ilgili duygular" alt boyut puanı 14.70 \pm 3.61 'dir. Literatürde puan ortalamalarının benzer olduğu çalışmalar (Aslan, \& Gürdap, 2021, ss. 84-98; Baran ve ark, 2020, ss. 352-359; Daştan, \& Hintistan, 2018, ss. 1-9) bulunmaktadır. Ancak Şadi Şen, Yurt (2021) ile Menekli ve Korkmaz'ın (2021) çalışmalarında puan ortalamaları sırasıyla $8.13 \pm 3.70,8.91 \pm 2.7$ ile farklı ve daha düşüktür. $\mathrm{Bu}$ durumun kurumun kanıta dayalı uygulamalara yönelik gerçekleştirdiği faaliyetler ve çalışanların bu konudaki motivasyonlarından kaynaklanabileceği düşünülmektedir. "Kanıta dayalı hemşirelikle ilgili duyguları" konunun önemini, klinik yararları ve hemşirenin duygularını içermektedir (Ayhan ve ark., 2015, ss. 21-35). Gerçekleştirilen çalışmada hemşirelerin "kanıta dayalı hemşirelikle ilgili duygularının" olumlu yönde ancak geliştirilmesi gerektiği sonucuna ulaşılmıştır.

Hemşirelerin çalıştıkları hastane türü ile KDHYTÖ ve alt boyutlarının puan ortalamaları arasında istatistiksel olarak fark bulunmamıştır. Literatürde özellikle üniversite hastanelerinde çalışanların devlet hastanelerinde çalışanlara göre kanıta dayalı uygulamalara daha pozitif yaklaştığı belirtilmektedir (Yılmaz, Çeçen, Aslan, Kara, Kızıl Toğaç, \& Mutlu, 2018, ss. 235241).

Bu araştırmada, hemşirelerin yaş gruplarına göre KDHYTÖ "kanıta dayalı hemşireliğe yönelik inanç ve beklentiler" alt boyutunda fark olduğu ancak istatistiksel olarak farkın anlamlı 
olmadığı belirlenmiştir. Doğan ve arkadaşlarının çalışmasında (2021) yaş değişkeninin ölçek toplamı ve inanç alt boyutu ile pozitif yönde anlamlı korelasyonu olduğu belirlenmiştir. Ayrıca yaşın artması ile tutumların olumlu etkilendiği belirtilmiştir. Menekli ve Korkmaz (2021)'ın çalışmalarında yaşı 25 'den küçük olanların tutumlarının daha olumlu olduğu belirtilmiştir. Bazı çalışmalarda ise yaşın KDHYTÖ ve alt boyutları puan ortalamalarında anlamlı bir fark oluşturmadığ1 saptanmıştır (Aslan, \& Gürdap, 2021, ss. 84-98; Baran ve ark., 2020, ss. 84-92; Yılmaz ve ark, 2019, ss. 713-719). Yeni mezun hemşirelerin kanıta dayalı hemşireliğe yönelik güncel bilgilere sahip olabileceği ve tutumlarının olumlu olabileceği düşünülmektedir.

Cinsiyet değişkeninin kanıta dayalı tutumları etkilemediği belirlenmiştir. Bazı araştırmalarda benzer sonuçlara ulaşılırken (Doğan ve ark., 2021, ss. 612-622; Şadi Şen, \& Yurt 2021, ss. 102-107; Aslan, \& Gürdap 2021, ss. 84-92) farklı sonuç elde edilen çalışmaya rastlanmamıştır. Bu durumdan yola çıkarak hemşirelerin kanıta dayalı tutumlarında cinsiyetin bir faktör olmadığı söylenebilir.

Lisans eğitimine sahip hemşirelerin lise ve ön lisans eğitimi alan hemşirelere göre ölçek toplamı, "kanıta dayalı uygulama niyeti" ve "kanıta dayalı hemşirelikle ilgili duygular" alt boyut puan ortalamalarının daha yüksek olduğu belirlenmiştir. Aslan ve Gürdap (2021) ile Doğan ve arkadaşlarının (2019) çalışmalarında eğitim durumunun etkili bir değişken olmadığı belirlenmiştir. Bazı çalışmalarda eğitim düzeyinin tutumlarda belirleyici olduğu aktarılmıştır. Lisans ve lisansüstü eğitimine sahip hemşirelerin kanıta dayalı tutumları anlamlı düzeyde farklıdır (Baran ve ark., 2020, ss. 352-359; Menekli, \& Korkmaz, 2021, ss. 38-47; Y1lmaz ve ark., 2019, ss. 713-719). Eğitim düzeyi arttıkça hemşirelerin kanıta dayalı tutumları gelişmektedir (Koehn, \& Lehman; 2008, ss. 209-215; Şadi Şen, \& Yurt 2021, ss. 102-107).

Araştırma sonucunda, servislerde çalışan hemşirelerin KDHYTÖ puanı ve "kanıta dayalı uygulama niyetinin" diğer birimlere göre anlamlı düzeyde yüksek olduğu belirlenmiştir. Yapılan bazı çalışmalarda çalışılan birimin hemşirelerin tutumlarında farka yol açmadığ bulunmuştur (Aslan, Gürdap, 2021, ss.84-92; Y1lmaz ve ark., 2019, ss. 713-719; Y1lmaz ve ark., 2018, ss. 235-241). Doğan ve arkadaşlarının 2019 yılındaki çalışmasında yoğun bakım çalışanlarının dahili ve cerrahi servislerindeki çalışanlara göre "kanıta dayalı uygulama niyeti" puan ortalamalarının daha yüksek olduğunu saptamıştır (Doğan ve ark., 2021, ss. 612-622). Başka bir çalışmada da, cerrahi yoğun bakımda çalışan hemşirelerin cerrahi servisi ve ameliyathane hemşirelerine göre "kanıta dayalı uygulama niyeti" puan ortalamalarının daha yüksek ve anlamlı olduğu ifade edilmektedir (Y1lmaz ve ark., 2018, ss. 235-241). Ancak bizim araştırmamızda servislerde çalışan hemşirelerin kanıta dayalı uygulama niyetleri ve kanıta yönelik tutumlarının daha ileri düzeyde olması ameliyathane, yoğun bakım ve acil servisteki meslektaşlarına göre daha az yoğun olması ve yeterli zaman ayıracaklarını düşünmelerinden dolayı olabileceği söylenebilir.

Araştırmaya katılan hemşirelerin tutumlarını kurumdaki çalışma yılının etkilemediği bulunmuştur. Yapılan diğer çalışmalarda bu araştırmadan farklı olarak, kurumdaki çalışma süresinin kanıta dayalı tutumlarda farklılığa yol açtığı bildirilmiştir (Baran ve ark., 2020, ss. 352-359; Y1lmaz ve ark., 2019, ss. 713-719). Menekli ve Korkmaz (2021) bu araştırmanın tam zıttı bir şekilde 1-6 yıl çalışma deneyimine sahip hemşirelerin kanıta dayalı tutumlarının daha yüksek olduğunu aktarmıştır. Başka bir çalışmada görev süresi 0-12 ay olan hemşirelerin kanıta dayalı tutumlarının daha yüksek olduğu belirtilmiştir (Şadi Şen, \& Yurt 2021, ss. 102-107). Bu araştırma için; hemşirelerin çoğunun kurumda yeni başlayan hemşire olarak çalışması uyum sorunları yaşamalarına yol açarak bu durumu etkilemiş olabilir.

Araştırmada, mesleki derneklere üyelik ve araştırma yapma isteği ile hemşirelerin KDHYTÖ ve alt boyutları arasında istatistiksel açıdan anlamlı bir fark bulunamamıştır. Yapılan 
diğer çalışmalar mesleki derneklere üyelik konusunda araştırma bulgularıyla uyumludur (Doğan ve ark., 2021, ss. 612-622; Şadi Şen, \& Yurt 2021, ss. 102-107; Menekli, \& Korkmaz, 2021, ss. 38-47). Ancak Menekli ve Korkmaz (2021) çalışmasında bilimsel araştırma yapan ve toplantılara katılan hemşirelerin kanıta dayalı tutumlarının olumlu olduğunu bulunmuştur. Aynı şekilde Doğan ve arkadaşları (2019) çalışmasında araştırma isteği ile kanıta dayalı uygulamaya yönelik tutumlar arasında anlamlı ilişki olduğunu belirtilmiştir. Araştırma yapan hemşirelerin güncel bilgilere daha hakim olabileceği ve bireysel ve mesleki yönden geliştikleri dolayısıyla tutumlarının olumlu olabileceği düşünülmektedir.

Hemşirelerin mesleki yayın okuması KDHYTÖ "kanıta dayalı hemşirelikle ilgili duygular" alt boyutunu etkilemektedir. Bilimsel yayınları takip etmek hemşirelerin kanıta dayalı uygulamalardaki tutumlarını geliştirmektedir (Aslan, \& Gürdap, 2021, ss. 84-98; Şadi Şen, \& Yurt 2021, ss. 102-107). Bir çalışmada mesleki yayınları takip etmenin sadece "kanıta dayalı uygulama niyeti" alt boyutunu etkilediği (Yılmaz ve ark., 2019, ss. 713-719), başka bir çalışmada da bilimsel dergi okumanın "kanıta dayalı hemşireliğe yönelik inanç ve beklentiler" alt boyutunda farklılığa yol açtığı sunulmuştur.

Yaşamının çoğu kentsel alanda geçiren hemşirelerin, kanıda dayalı tutumları ve "kanıta dayalı hemşireliğe yönelik inanç ve beklentileri” kırsal alanda olanlara göre daha yüksektir. Literatürde böyle bir bilgiye rastlanmamıştır. Kentsel alanda uzun süre yaşamını geçiren hemşirelerin bilgi, teknoloji kullanımı, araştırmaya ve yayın takip etme gibi olanaklarının kırsal alanda olan hemşirelere göre daha fazla olabileceği düşünülmektedir.

\section{Araştırmanın sınırlılıkları}

Araştırmanın sadece bir ilçedeki hastanelerde gerçekleştirilmiş olması bu araştırmanın sınırlılığıdır. Kamu hastanelerinde araştırmaya katılım istendik (\%65) değerin altında kalsa da kabul edilebilir (en az \%40) seviyededir (Polit, \& Beck, 2008).

\section{SONUÇ VE ÖNERILER}

Araştırmaya katılan hemşirelerin kanıta dayalı hemşireliğe yönelik tutumlarının olumlu yönde olduğu saptanmıştır. Hemşirelerin yaş, eğitim durumu, çalıştıkları birim, yaşanılan yer, mesleki yayın okuma değişkenlerinin kanıta dayalı hemşireliğe yönelik tutumlarında etkileyen faktörler olduğu belirlenmiştir.

Hemşirelerin kanıta dayalı tutumlarının geliştirilmesinde; uygulama engellerinin ortadan kaldırılması ve klinik iş yükü, zaman yetersizliği vb. nedenlerle klinik uygulamaya kanıtların entegre edilemediği durumlarda yönetsel desteğin artırılması ve hem kurumsal hem de Sağlık Bakanlığı düzeyinde kolaylaştırıcı/düzeltici faaliyetlerin gerçekleştirilmesi önerilmektedir. Ayrıca, lisans eğitiminden itibaren konunun önemine dikkat çekilmesi, klinik bakımları kanıta dayalı yapan hemşirelerin bakımda yarattı̆̆ farkları ekip üyeleri ve diğer birimlerdeki çalışanlarla paylaşması, hastane yönetimlerinin güncel bilgilerin kliniğe entegrasyonunda kolaylaştırıcı rolleri üstlenmesi, bakım ortamlarını ve çalışma koşullarını iyileştirmesi ve çalışanların bu konudaki performans ve motivasyonlarını geliştirmesi önerilmektedir. Araştırmacılara bakımın farklı alanlarında kanıta dayalı uygulamaların kullanımına yönelik projeler üretmesi önerilmektedir.

\section{KAYNAKLAR}

André, B., Aune, A. G., \& Brænd, J. A. (2016). Embedding evidence-based practice among nursing undergraduates: results from a pilot study. Nurse Education in Practice, 18, 30-35. 
Aslan, H., \& Gürdap, Z. (2021). Hemşirelerin kanıta dayalı hemşireliğe yönelik tutumları ve periferik venöz kataterle ilişkili enfeksiyonu önlemeye yönelik bilgi düzeyleri. The Journal of Turkish Family Physician, 12(2), 84-98.

Ayhan, Y., Kocaman, G., \& Bektaş, M. (2015). Kanıta Dayalı Hemşireliğe Yönelik Tutum ölçeği'nin Türkçe'ye uyarlanması: geçerlik ve güvenirlik çalışması. Hemşirelikte Araştırma Geliştirme Dergisi, 17(2/3), 21-35.

Baran, G. K., Atasoy, S., \& Şahin, S. (2020). Hemşirelerin Kanıta Dayalı Hemşirelik Uygulamalarına Yönelik Farkındalık ve Tutumlarının Değerlendirilmesi. Celal Bayar Üniversitesi Sağlık Bilimleri Enstitüsü Dergisi, 7(3), 352-359.

Daştan, B., \& Hintistan, S. (2018). Dahiliye kliniklerinde çalışan hemşirelerin kanıta dayalı hemşireliğe yönelik tutumlarının belirlenmesi: kırsal bölge örneği. Ordu Üniversitesi Hemşirelik Çalışmaları Dergisi, 1(1), 1-9.

Doğan, S. D., Karaçay, S. Y., Arslan, S., Yurtseven, Ş., Nazik, E., \& Yüksekkaya, S. E. (2019). Bir Üniversite Hastanesinde Çalışan Hemşirelerin Kanıta Dayalı Hemşireliğe Yönelik Tutumları. Ankara Sağlık Bilimleri Dergisi, 8(2), 39-45.

Doğan, E. S., Aynur, C., Demirağ, H., \& Uçan, M. F. U. (2021). Hemşirelerin Kanıta Dayalı Hemşirelik Uygulamalarına Yönelik Tutumlarının İncelenmesi. Uluslararası Anadolu Sosyal Bilimler Dergisi, 612-622.

Gravetter, F., \& Wallnau, L. (2014). Essentials of statistics for the behavioral sciences (8th ed.). Belmont, CA: Wadsworth.

Ingersoll, G. L. (2000). Evidence-based nursing: what it is and what it isn't. Nursing Outlook, 48(4), 151-152.

Jennings, B. M. (2000). Evidence-based practice: The road best traveled?. Research in Nursing \& Health, 23(5), 343-345.

Koehn, M. L., \& Lehman, K. (2008). Nurses' perceptions of evidence-based nursing practice. Journal of Advanced Nursing, 62(2), 209-215.

Menekli, T., \& Korkmaz, M. (2021). Dâhiliye Hemşirelerinin Kanıta Dayalı Hemşireliğe Yönelik Tutumları. Dokuz Eylül Üniversitesi Hemşirelik Fakültesi Elektronik Dergisi, 14(1), $38-47$.

Polit D. F. \& Beck C. T. (2008). Nursing Research: Generating and Assessing Evidence for Nursing Practice. Lippincott Williams \& Wilkins, Philadelphia, PA.

Registered Nurses' Association of Ontario-(RNAO). (2021). Best Practice Guidelines. Erişim Tarihi: 29.11.2021. Erişim Linki: https://rnao.ca/bpg/guidelines

Reigle, B. S., Stevens, K. R., Belcher, J. V., Huth, M. M., McGuire, E., Mals, D., \& Volz, T. (2008). Evidence-based practice and the road to magnet status. JONA: The Journal of Nursing Administration, 38(2), 97-102. 
Ruzafa-Martínez, M., López-Iborra, L., \& Madrigal-Torres, M. (2011). Attitude towards Evidence-Based Nursing Questionnaire: development and psychometric testing in Spanish community nurses. Journal of Evaluation in Clinical Practice, 17(4), 664-670.

Şadi Şen, E. \& Yurt, S. (2021). Hemşirelerin Kanıta Dayalı Uygulamalara Yönelik Tutumlarının Belirlenmesi. Dokuz Eylül Üniversitesi Hemşirelik Fakültesi Elektronik Dergisi, 14(2), 102-107.

T.C. Sağlık Bakanlığı. (2011). Hemşirelik Yönetmeliğinde Değişiklik Yapılmasına Dair Yönetmelik. Resmi Gazete. Tarih:19 Nisan 2011, Sayı: 27910). Erişim Tarihi: 29.11.2021. Erişim Linki: https://www.saglik.gov.tr/TR,10533/hemsirelik-yonetmeligi.html

Türk Dil Kurumu (2021). Kanıt. Erişim Tarihi: 29.11.2021. Erişim Linki: https://sozluk.gov.tr/

Türk Hemşireler Derneği (THD). (2009). "Hemşireler için Etik İlke ve Sorumluluklar” . Erişim Tarihi: 29.11.2021. Erişim Linki: https://www.thder.org.tr/uploads/files/hemsire-brosur.pdf

Yılmaz, D., Düzgün, F., \& Dikmen, Y. (2019). Hemşirelerin kanıta dayalı hemşireliğe yönelik tutumlarının incelenmesi. Acıbadem Üniversitesi Sağlık Bilimleri Dergisi, (4), 713-719.

Yılmaz, E., Çeçen, D., Aslan, A., Kara, H., Kızıl Toğaç, H., \& Mutlu, S. (2018). Cerrahi kliniklerde çalışan hemşirelerin kanıta dayalı hemşireliğe yönelik tutumları ve araştırma kullanımında algıladıkları engeller. Hemşirelikte Eğitim ve Araştırma Dergisi, 15(4), 235-241.

Wilson, M., Sleutel, M., Newcomb, P., Behan, D., Walsh, J., Wells, J. N., \& Baldwin, K. M. (2015). Empowering nurses with evidence-based practice environments: Surveying Magnet ${ }^{\circ}$, Pathway to Excellence ${ }^{\circledR}$, and non-magnet facilities in one healthcare system. Worldviews on Evidence-Based Nursing, 12(1), 12-21. 